\title{
Towards sustainable water resources for arid land cities: the case of Riyadh
}

\author{
A. A. Alhawas \\ Geog. Dept. King Saud University, Riyadh, Saudi Arabia
}

\begin{abstract}
Owing to the aridity prevailing in the region, Riyadh is very poor in renewable water resources. Internal renewable water resources are estimated at $1577 \mathrm{~m}^{3} \mathrm{yr}^{-1}$ per inhabitant. The total withdrawal of water is greater than the total actual renewable water resources. This applies a great deal of stress on planning water resources and water use for development sustainability. Fortunately for the city of Riyadh, it is located on the Arabian shield where ground water resources have always been a major source of city potable and irrigation waters. Deep ground water sources supply the city with more than $40 \%$ of its daily water consumption. But the recharge rate is way below the withdraw rate, annual PPT average $100 \mathrm{~mm}$. However, the fast growth of the city is imposing serious challenges on water supply planning. The ground water sources by the city are exhausted, and their $40 \%$ share in city water supply is not tenable. The city planners are assuming an increasing share of desalinated seawater for the city supply. Expected city average daily consumption of water in 2014 is $2768639.015 \mathrm{~m}^{3}$, of which the current ground water supply is $20 \%$. The rest is to be supplied from other sources. It is concluded that all other potential sources should be fully utilized in order to reduce pressure on ground and desalinated water sources, including cloud seeding, rain harvesting and water reuse. It is also recommended that huge amounts of water can be saved by maintaining the city distribution net, and by other means like raising public awareness.
\end{abstract}

Keywords: ground water, desalination, recycling, formations, fossil water, recharge, outcrop, Riyadh, Saudi Arabia, urbanization.

\section{Introduction}

Potable water availability is becoming a problem in many places on the planet. Water security is an important component of human living security, and their 
food supply. Urban clusters and cities are key factors in maintaining human development and welfare on earth. Growing populations and rapid urbanization have caused serious water scarcity and widened the gap between supply and demand of the precious substance. Sustainability requires renewable or maintainable essential resources. Water resources are essential for municipal purposes that could slow or even halt the urbanization process if not well sustained (Fang and Xie [1], Bao and Fang [2]). For the city of Riyadh, sustainable water supply is a key factor in city growth. Situated in the very middle of the Arabian Peninsula, in a hyper-arid environment with an average annual precipitation of $100 \mathrm{~mm}$, the water shortage is increasing as the city expands. This paper describes a case study of water consumption in Riyadh city as a rapidly growing urban body, where water resources are insufficient to satisfy the growing demand. The overall water resources situation in the whole country is laid down first, then the city growth and water supply are discussed, possible solutions are suggested.

\subsection{National water resources and policies}

The Arabian Peninsula can be divided into two structural units: the Arabian Shield composed of crystal rocks in the west, and the Arabian Shelf. The Arabian Shelf lies to the east of the shield where it forms about two thirds of the peninsula area. It is composed of a sequence of sedimentary layers laying on the shield rocks and dip gently away from the shield and into a number of deep basins. The sequence is formed of continental and marine sedimentary rocks, due to successive transgression and regression cycles of the gulf waters (Aiban [3]). They reach their highest thickness of $10 \mathrm{~km}$ at the Arabian Gulf coast (Alhawas [4]). Sedimentary layers of the Arabian Shelf are of varying hydrological characteristics. Scanty annual precipitation ranges between $70-200 \mathrm{~mm}$ in the centre and north, however it may fall below $70 \mathrm{~mm}$ in the south and exceeds 500 $\mathrm{mm}$ in southwest. Overall precipitation is estimated to be $59 \mathrm{~mm} \mathrm{yr}^{-1}$, which over the whole country sums up to $126.8 \mathrm{~km}^{3} \mathrm{yr}^{-1}$.

Owing to the aridity prevailing in the region, Saudi Arabia is very poor in renewable water resources. Internal renewable water resources are estimated at $1577 \mathrm{~m}^{3} \mathrm{yr}^{-1}$ per inhabitant. The total withdrawal of water is greater than the total actual renewable water resources (Mortada [5]). This applies a great deal of stress on planning water resources and water use for development sustainability. Therefore, water resources development plans rely on fossil water and nonconventional water resources to satisfy the excess demand on water that renewable sources cannot satisfy.

In the 80 s of the last century the total ground water reserve in Saudi Arabia was estimated to be 500 billion $\mathrm{m}^{3}$ (Othman [6]), other sources estimates are up to 2000 billion $\mathrm{m}^{3}$ (Edgell [7]). Deep ground waters (DGW) contributed $12400 \mathrm{Mm}^{3}$ to the water budget in 2004, increasing from $11769 \mathrm{Mm}^{3}$ in 1999 (Ministry of Economy and Planning [8]). DGW contributed $11551 \mathrm{Mm}^{3}$ in 2009, but the plans are aiming at reducing its share in the national water budget by $4.9 \%$ per annum to reach $8976 \mathrm{Mm}^{3}$ by 2014 (Ministry of Economy and Planning [9]). 
Nowadays, Saudi Arabia is the largest producer of desalinated sea water in the world. There are currently 30 desalination plants in the country, distributed on the east and west coasts. Total production capacity is $2.877 \mathrm{Mm}^{3}$ day $^{-1}$. Actual total production (ATP) in the year 2004 was $1064.90 \mathrm{Mm}^{3}$ a significant increase from $797.38 \mathrm{Mm}^{3}$ in the year 2000 (SWCC [10]). New plants under construction will add $580000 \mathrm{~m}^{3}$ day $^{-1}$ (SWCC [10]), a total of $20.9 \mathrm{Mm}^{3} \mathrm{yr}^{-1}$. ATP dropped to $1014.21 \mathrm{Mm}^{3}$ in 2009 (SWCC [11]), but it is expected to reach $2052 \mathrm{Mm}^{3}$ by year 2014 (MEP [9]).

The general average utilization of treated water has increased from $32 \%$ in year 2000 to $33.5 \%$ in 2004 . There is a great deal of variability between cities in utilizing sewage waters, ratios vary from 100\% in Aljubail, 40\% in Riyadh city and nil in many other cities. In general, it provides $260 \mathrm{Mm}^{3} \mathrm{yr}^{-1}$. This figure has increase to $390 \mathrm{Mm}^{3}$ in 2009 and it is planned to reach $750 \mathrm{Mm}^{3} \mathrm{yr}^{-1}$ by 2014.

\section{The city of Riyadh water project}

The Ministry of Agriculture and Water, as it was then, established several large and self-contained projects to extract subterranean water in order to satisfy the growing population demand on water. The largest is the water project in the city of Riyadh. Riyadh water project, responsible for managing the city supply of water (quantity and quality) and its distribution is striving to cope with accelerating city growth. The city receives its water supply from renewable and non-renewable sources. Renewable sources include surface and shallowunconfined wadi-alluvium aquifers in addition to sea desalinated and treated sewage waters.

\subsection{A desperate search to satisfy an overwhelming demand}

With a total population of more than 4 million people in 2004 (Ministry of Economics and Planning [8]), Riyadh city occupies $\sim 1600 \mathrm{~km}^{2}$, in a hyper-arid environment. The city is situated on the limestone of upper Jurassic Jubailah and Arab formation plateaus, and is located in Wadi Hanifah basin. It is underlied by the thick sequence of sedimentary rocks of the Arabian Shelf, which include the aquifers of Jilh, Minjur, Jubailah, Biyadh and Wasia (table 1). At a very early stage of city development, in the early 1950s, natural springs and seeps in Wadi Hanifah provided enough supply of water. Water-table hand-dug open wells were built later to accommodate the growing demand as the city population reached $\sim 80000$. City growth, and the failure of water-table wells during dry years, especially in hot summer months, where large numbers of Bedouins are forced to resort to urban areas, necessitates the search for more reliable water sources. The shallow alluvial aquifer of Hair $30 \mathrm{~km}$ south of the city was utilized in late 1950s. Followed by the first deep well ( $>1300 \mathrm{~m}$ deep) to be dug in Minjur, the Shumaisy well which, started production in 1957. Minjur aquifer became a major source of water for Riyadh municipal supply during the 1960s and 1970s (Al-Mutaz [12])). in 1977 there were 37 Minjur wells supplying the city with water, but the low quality of Minjur waters necessitate the 
Table 1: $\quad$ Sample of principal ground water formations.

\begin{tabular}{|c|c|c|c|c|c|c|}
\hline \multirow[b]{2}{*}{ Formation } & \multicolumn{2}{|c|}{ Area $\mathrm{km}^{2}$} & \multirow{2}{*}{$\begin{array}{c}\text { Water } \\
\text { reserve } \\
\text { Estimates } \\
\text { Billion } \mathrm{m}^{3} \\
\end{array}$} & \multirow{2}{*}{$\begin{array}{l}\text { Withdraw } \\
\mathrm{Mm}^{3} \mathrm{yr}^{-1}\end{array}$} & \multirow{2}{*}{$\begin{array}{l}\text { Recharge } \\
\mathrm{Mm}^{3} \mathrm{yr}^{-1}\end{array}$} & \multirow[b]{2}{*}{ T.D.S. } \\
\hline & Total & Outcrop & & & & \\
\hline Saq & 160000 & 65000 & 280 & 300 & 290 & 680 \\
\hline Wajid & - & 31000 & 205 & 25 & 114 & 1200 \\
\hline $\begin{array}{c}\text { Minjur\& } \\
\text { Dhruma }\end{array}$ & 90000 & 6500 & 85 & $>105$ & 99.6 & \\
\hline $\begin{array}{l}\text { Wasia- } \\
\text { Biyadh }\end{array}$ & 130000 & & 290 & & 480 & \\
\hline $\begin{array}{c}\text { Umm er } \\
\text { Radhumma }\end{array}$ & 132000 & & 75 & & 1048 & 2820 \\
\hline
\end{tabular}

Data sources: (Edgell [15]; Othman [6]; and Sharaf [16]).

establishment of three treatment plants with total capacity of $148000 \mathrm{~m}^{3}$ day $^{-1}$ for the purpose of purifying water (Allard and Treille [13]). With the increasing demand and the city population exceeding 600000, more aquifers are to be utilized. Biyadh well field $40 \mathrm{~km}$ south of Riyadh was completed and started production in 1964. Biyadh well field consists of 22 wells producing $47000 \mathrm{~m}^{3}$ day $^{-1}$. Due to declining water in Minjur wells dug within the city, production from Minjur was shifted to sites away from the city. In 1978 Salbukh well field, $50 \mathrm{~km} \mathrm{NW}$ of Riyadh, began production. It consists of 16 wells their average depth is $1500 \mathrm{~m}$, and produces a total of $60000 \mathrm{~m}^{3}$ day $^{-1} .65 \mathrm{~km} \mathrm{NE}$ of Riyadh Buaib well field began production from its 18 wells of average $1800 \mathrm{~m}$ deep. It produces $80000 \mathrm{~m}^{3}$ day $^{-1}$. As the city population approaches a million people, a farther away well field of Wasia located $110 \mathrm{~km}$ E. of the city, was developed in 1981 to produce water from Wasia and Biyadh aquifer. The Wasia project consists of 63 wells, of average depth $450 \mathrm{~m}$, producing $200000 \mathrm{~m}^{3}$ day $^{-1}$. The 1992 population census showed 2776096 people residing in Riyadh city. Anticipating the very rapidly growing demand on water, the search for other sources led to Alheni well field located $218 \mathrm{~km} \mathrm{E}$. of the city. It started production in 2005, from 65 wells of average depth $450 \mathrm{~m}$. Alheni wells are dug in Umm er Radhuma aquifer, and are capable of producing $350000 \mathrm{~m}^{3}$ day $^{-1}$ (Fig. 1) (WSA [14]). Starting 1959 several dams were constructed around the city, for recharge and flood control purposes; there total capacity is more than $9 \mathrm{Mm}^{3}$. water behind the dams is mainly used for agriculture, though dam lakes may run dry in dry seasons. Ground water sources supply the city with only $40 \%$ of its water consumption.

\subsection{Desalinated water}

As the city of Riyadh, keeps on growing it became evident that the carrying capacity of all conventional water resources will be reached without satisfying the rapidly increasing demand for water. In order not to allow the water problem to limit the city growth, and with a booming economy, the city started in 1983 receiving desalinated water from Aljubail II desalination plant on the E. coast. 


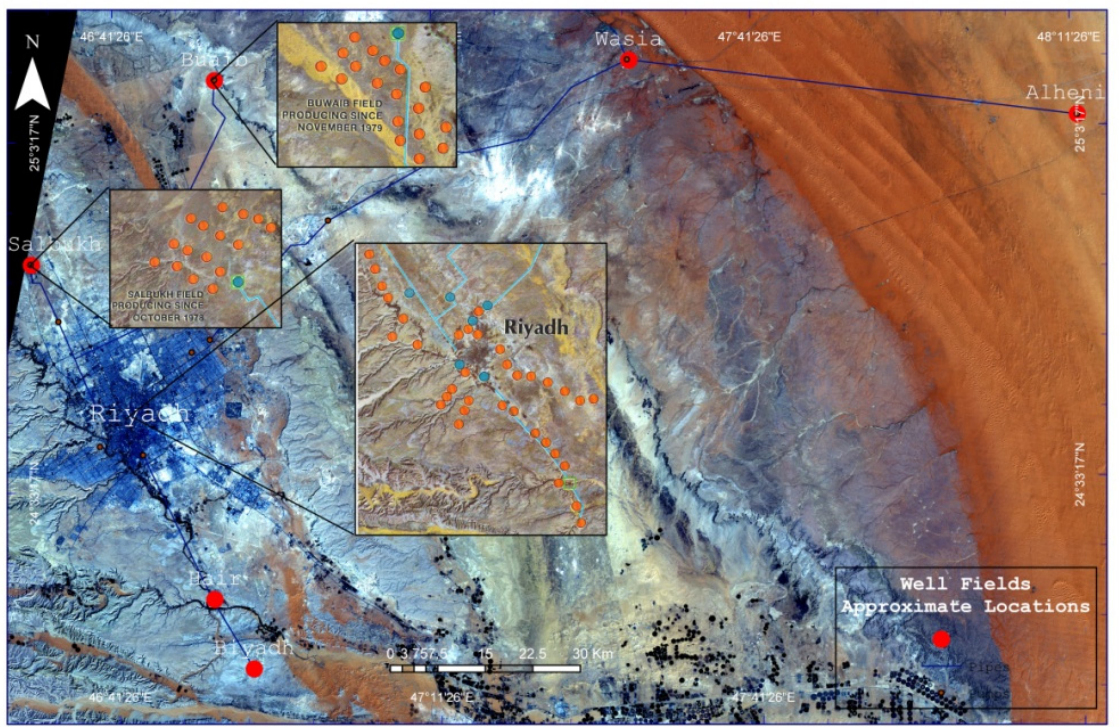

Figure 1: Water well fields supplying Riyadh, (for colour view the reader is referred to the web version of this article).

The plant has a capacity of producing $815185 \mathrm{~m}^{3}$ day $^{-1}$. In 1994 the plant pumped an average amount of $780000 \mathrm{~m}^{3}$ day $^{-1}$, in 2004 this figure became $810000 \mathrm{~m}^{3}$ day $^{-1}$, almost the plant capacity (SWCC [10]). Water coming out of the plant is gathered in 5 huge tanks with capacity $682500 \mathrm{~m}^{3}$ and pumped to the city throw a dual pipe line $466 \mathrm{~km}$ long. The pipe system has 6 pumping stations along its way to help elevate the water from sea level to $692 \mathrm{~m} \mathrm{ASL}$. Here the desalinated water is collected in 6 tanks that can store $300000 \mathrm{~m}^{3}$ and mixed with ground water from Wasia well field before it goes into the city system. The city system has two emergency tanks that can store $3 \mathrm{Mm}^{3} .9^{\text {th }}$ development plan aims at increasing SWCC production by \%8.2 per annum between 2010 and 2014.

\subsection{Recycled water}

Recycled water is strictly used for industrial, machine cooling, purposes or for supervised agricultural and recreational irrigation around the city. Water is treated in two main plants of $400000 \mathrm{~m}^{3}$ day $^{-1}$ total capacity (Floyd [17]), in addition to a small plant of $3000 \mathrm{~m}^{3}$ day $^{-1}$. With the increase in city sewage discharge two plants of total capacity $300000 \mathrm{~m}^{3}$ day ${ }^{-1}$ are under construction (WSA [14]).

\subsection{Water distribution}

The city has two emergency reservoirs, in addition to three main water tanks connected to the water distribution net. The total capacity of all tanks is 
$3257500 \mathrm{~m}^{3}$. The net for water distribution adds up to $9860 \mathrm{~km}$ of pipes, with 299054 household connections. Average city daily consumption of water in 1972 was $100000 \mathrm{~m}^{3}$, in 2004 was $1137804 \mathrm{~m} 3$ and in 2010 it was $1728314 \mathrm{~m}^{3}$ day $^{-1}$. More than $60 \%$ of the water supply came from desalinated sea water; the rest was supplied from deep aquifers. City currently, receives a fixed quantity of $810000 \mathrm{~m}^{3}$ day $^{-1}$ from SWCC, and satisfies the monthly and daily fluctuation in water demand from ground water sources. Water per capita consumption in the city has declined from 549 litres day $^{-1}$ in 1989 to 257 litres day $^{-1}$ in 2004. This reduction was partially, due to maintaining the old city distribution pipe net and to the water awareness campaign (WSA [14]).

\subsection{Future demands on water}

Future water consumption estimates are usually calculated using population growth projections. For the city of Riyadh, population annual growth rate was $3.22 \%$ (1992-2004). The city water consumption for the same period had grown by an annual rate of $4.5 \%$. Limiting the future demand expectations solely to population per capita needs may be under estimating the actual future needs. The industrial provinces and the gardening and agricultural activities within the city are growing as such. So, city future demand on water was calculated using the following model:

$$
D_{t}=W C_{0} e^{k \cdot \Delta t}
$$

where:

$D_{t}=$ Demand on water at time t.

$W C_{0}=$ water consumption at initial time.

$\mathrm{K}=$ annual growth rate.

$\Delta \mathrm{t}=$ period in years.

The average daily consumption of water in Jan/2009 was used to be the initial time with average daily consumption of $1,382,589 \mathrm{~m}^{3}$, whole year average daily consumption was $1569943.9 \mathrm{~m}^{3}$, and for 2010 it was $1728313.7 \mathrm{~m}^{3}$. Actual consumption values for 2009 and 2010 were used to validate the model (Fig. 2).

In fig. 2, the inset is for a detailed look at 2009 and 2010, which shows the seasonal fluctuations. The city potable water demand is expected to double by 2014. Saline Water Conversion Corporation (SWCC) plans to increase production to support Riyadh water supply by $800000 \mathrm{~m}^{3} \mathrm{~d}^{-1}$ by that time, which may be good enough to satisfy the rapidly growing demand, only if the mixing ratio with ground water is to be maintained. Obviously, this difficult task cannot be achieved without utilizing new sources. 2050 Projections are far more alarming and the numbers are far more than what conventional resource could imaginably be utilized to cope with, even with the desalination plants supplying $60 \%$ of the needed water. 


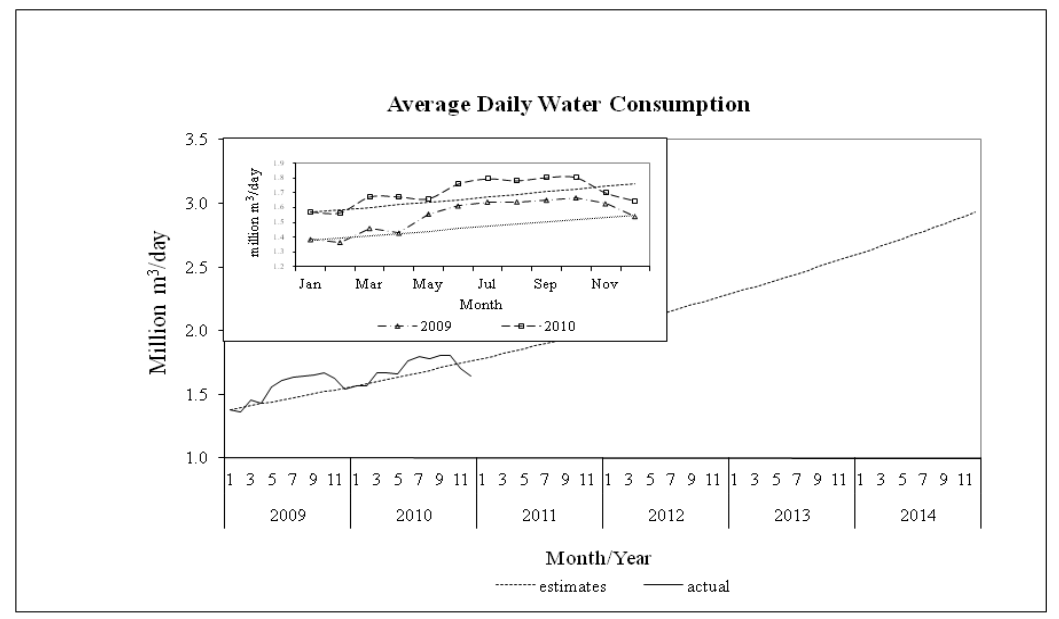

Figure 2: $\quad$ Riyadh future water demands.

Table 2: $\quad$ Riyadh city future demand on water.

\begin{tabular}{|c|c|c|c|c|}
\hline Year & Population & $\begin{array}{c}\text { Desalinated } \\
\text { water }\end{array}$ & Ground water & $\begin{array}{c}\text { Water } \\
\text { consumption } \mathrm{m}^{3} \\
\text { day }^{-1}\end{array}$ \\
\hline 1974 & 665504 & & - & - \\
\hline 1992 & 2776096 & - & 142152 & 415486 \\
\hline 1999 & - & 273234 & 397464.8 & 993662 \\
\hline 2001 & 3709309 & 596197.2 & 455121.6 & 1137804 \\
\hline 2004 & 4087152 & 682682.4 & 759944 & 1569944 \\
\hline 2009 & & 810000 & 918314 & 1728314 \\
\hline 2010 & 4959226 & 810000 & 1107456 & $2768639^{*}$ \\
\hline 2014 & & 1661183 & 937305.6 & $2343264 *$ \\
\hline 2020 & & 1405958.4 & 3632196.4 & $9080491^{*}$ \\
\hline 2050 & & 5448294.6 & &
\end{tabular}

*Projected values

\section{Solutions}

Continued population growth over the coming decades can only exacerbate the existing water crisis. The crisis is further aggravated by the simultaneous increase in industrial and agricultural activities. Water shortage will accumulate with time, as the ground water resources around the city are exhausted and fall short from coping with the forever-growing demand on potable water. The situation is worsening by the fact that working desalination plants are approaching their expected installation life span. In the last few years starting 
2004, their production has to be reduced by $30 \%$ (SWCC [10]) because of maintenance. In the city of Riyadh sustainability problems are pressing. Solutions fall into two components, conserving water, and improving resources.

\subsection{Conserving water}

\subsubsection{Better management}

\subsubsection{Net maintenance}

The city WSA could save more than $315000 \mathrm{~m}^{3}$ day $^{-1}$ by reducing leakage from city net. The city distribution net needs extensive renovations, in order to reduce the leakage figures estimated by ministry of economy and planning to be $28.5 \%$ (Ministry of Economy and Planning [8]). beside its bad consequences on buildings and roads around the city, the huge amount of water dumped daily into the ground is very precious and scarce commodity. Urgent attention to maintaining the city water net is badly needed.

\subsubsection{Emergency response time}

993 is the emergency number for water leakage, the emergency team first task is to stop water leakage, then file a maintenance sheet and submit it to maintenance dept. who would evaluate the problem and provide parts and schedule the repair. It is the opinion of the writer, out of practical experience, that the emergency teams are not well allocated around the cit. they are not well equipped, and probably they are short in number to cope with the huge spatial extent of the city. Less than 40 emergency teams will never be able to efficiently maintain a water pipe net covering $1600 \mathrm{~km} 2$, supplying more than 4million people $(299054$ clients). Therefore, their response time is so long. 2004 statistics shows that they have responded to 70693 emergency calls (WSA [14]). The less response time means less quantity of potable water spoiled in the streets.

\subsubsection{Limited time shift distribution}

WSA have had adopted a shift-based distribution program. The city is divided into sub-zones; water is pumped for each sub-zone for a few hours each week or bi-weekly. Such solution should be a temporary one for two reasons. First, the time spans between zone shifts are going to be increasing as the city grow and spatially expand. Second, the alternating water pressure inside net pipes in the sub-zones, during dry periods and pumping shifts have made the pipes more vulnerable to damages. Worse, the damages are not easily discovered, because of short time of water flow inside pipes, and consequently less water pressure.

\subsubsection{Improve people awareness}

WSA have had launched a water conservation campaign, to raise the city people awareness of water as a scarce and precious substance. Media programs flyers posters and ads were devoted to raise people level of appreciation and knowledge about water scarcity problem. Thousands of attachments that help reduce water discharge from household and public places water faucets, and toilet flushes 
were distributed. According to water and sanitation agency, such efforts have helped reduce the daily per capita water expenditure in the city to 278 litres.

\subsubsection{Mandatory laws}

The instalment of the water conserving attachments was not made mandatory by law. In addition, national standards for locally manufactured or imported plumbing and sanitary parts are not in favour of more water conserving models. Regulations in this regards are becoming a necessity, and they would be more influential if passed in all GCC countries. Furthermore, the successful experiment made in Mecca province, mandating major commercial, industrial and residential projects installing recirculation facilities for toilet flushing and gardening would be very helpful if adopted in Riyadh.

\subsubsection{Water pricing and fines}

The average cost of one $\mathrm{m}^{3}$ of desalinated water is SAR1.78 (US \$0.47). The average cost of preparing one $\mathrm{m}^{3}$ of deep ground water for municipal use is SAR 0.98 (US \$0.26) (Al Mudaiheem et al. [18]; and Al-Rehail and Alabdula'aly [19]). Taking the mixing ratio of desalinated and ground water into account, the average cost of one $\mathrm{m}^{3}$ from the city net is SAR 1.46 (US \$0.39). The average revenue per $\mathrm{m}^{3}$, calculated using percentage of client billing in each pricing interval (table 3), is SAR 0.64 (US \$0.17). Prices and revenue are way below actual cost. However raising the prices may cause health and social setbacks especially for the lower income families. High water prices may force poor families to sustain from using water as much as necessary or they may resort to unsafe sources of water. So, if prices are to be reconsidered the very lower end of water tariff (may be $1-30 \mathrm{~m}^{3} /$ month) should be offered free or for low price. Actually, the first interval in the current Tariff offers a huge amount of water $\left(50 \mathrm{~m}^{3} /\right.$ month) for a very low price. The average family size in Riyadh is 6 people (ADA [20]). If daily individual consumption of 200 litres of water is assumed reasonable, the average house hold monthly consumption is expected to be $35 \mathrm{~m}^{3}$. Introducing a new Tariff is beyond the scope of this work but, the rest of the Tariff intervals should go exponentially up in price from there. WSA should enforce the fining against conservation violators. They should have more patrolling in the streets. Fining, will help increase water availability in two ways, first it will deter people from wasting water and secondly it will increase income to compensate the high cost of production.

Table 3: $\quad$ Water prices.

\begin{tabular}{|c|c|c|c|}
\hline $\begin{array}{c}\text { Consumption } \\
\mathrm{m}^{3} / \text { month }\end{array}$ & Price US $\$ \mathrm{~m}^{-3}$ & Price SAR $\mathrm{m}^{-3}$ & \% Client billings \\
\hline $1-50$ & 0.027 & 0.1 & 47.82 \\
\hline $51-100$ & 0.04 & 0.15 & 33.26 \\
\hline $101-200$ & 0.533 & 2.0 & 13.28 \\
\hline $201-300$ & 1.067 & 4.0 & 2.79 \\
\hline 301 & 1.6 & 6.0 & 2.85 \\
\hline
\end{tabular}

$\mathrm{SAR}=$ Saudi Riyals. 


\subsection{Improving resources}

\subsubsection{Cloud seeding and rain harvesting}

Seeding clouds is used to stimulate, and increase the amounts and frequency of scanty rain incidents (Xueliang et al. [21]), whereas, rain harvesting methods are applied to capture rain or runoff waters for later uses (Kossa [22]). These methods would be indirectly beneficial to the city potable water consumption, through the reduction of potable water use in irrigating gardens and small farms around the city.

\subsubsection{More ground water}

It is out of the question that $\mathrm{GW}$ resources in this region are not sustainable unless a balance between recharge and withdrawal is observed. GW resources around the city are over-exploited. Increasing the amount of GW to the city from currently exploited fields may lead to water quality deteriorations and serious sustainability issues. If additional fields must be utilized, probable candidates are the northern parts of Rub Alkhali (empty quarter) utilizing Wajid formation (table 1). Though faraway, but its elevation will help reduce the pumping cost to Riyadh.

\subsubsection{More desalination}

Increasing desalinated water supply to the city seems to be an inevitable necessity. The high cost of water desalination, and the necessary renovation to the old desalination plants are of great concern to any planner. Figures in table 4 above are projected assuming the ability to maintain the current mixing percentages between GW and DW. Such assumption does not seem to be tenable given the great deal of increase in water needs that the GW resource may be too exhausted to satisfy. For the year 2020, for example, the needed quantities of water for the city are not to be feasibly satisfied without adopting a cheaper and more productive desalination plants. Nuclear powered desalination may provide a more sustainable source of cheaper potable water for the Saudi cities.

\subsubsection{Water recycling}

Recycled water is being used for limited purposes and still in limited quantities. Though the city of Riyadh uses recycled water, yet great deal of the city discharge is not utilized. Not much being done in educating people and breaking the psychological barriers. New ways if integrating recycled waters into the city water supply must be adopted. Furthermore, the roles about digging shallow wells for villa-garden irrigation should be eased, to help reduce the percentage of city water used in gardening.

\section{Conclusion}

The numbers presented in this paper clearly show that the water problem in the city of Riyadh is becoming a strong constraint. Without an adequate framework within which to address this issue, there may be no legacy for the next generation in this city. It is the opinion of the writer that awareness about water scarcity 
problem though higher among individuals and government agencies in the Kingdome, still below the desired level. The awareness level should lead to significant changes in daily behaviour of individuals towards more water conservations. The reduction of individual daily consumption of water is a positive move into the right direction. However, more emphasis should be given to surface water utilization and rain harvesting where conditions allow since consumption numbers are way above internal total renewable resources capacity. Emergency measures must be taken to resolve water sustainability problem in the city. Such measure may include, but not limited to, innovating policies and technologies of water resources utilization, stronger management and planning of city water resources and limiting the city population and urbanization scales.

\section{References}

[1] Fang C. L., Xie Y. "Sustainable urban development in water-constrained Northwest China." J. Arid Environments, 74, 140-148, 2010.

[2] Bao Chao and Fang Chuang-lin, "Water resources constraint force on urbanization in water deficient regions: A case study of the Hexi Corredor, arid area of NW China." Ecological Economics, 62, 508517,2007.

[3] Aiban, Saad A. , "Compressibility and swelling characteristics of AlKhobar Palygorskite, eastern Saudi Arabia." Engineering Geology, Volume 87, Issues 3-4, 3 November 2006, Pages 205-219, 2006.

[4] Alhawas, Assaf A., "Water resources", in Geographic Encyclopedia of Muslim World, V. 3, No. 1, Kingdom of Saudi Arabia, Pages 825-910, Imam University, Riyadh, 1999.

[5] Mortada, H., "Confronting the challenges of urban water management in arid regions: geographic, technological, sociocultural, and psychological issues." Journal of Architectural and Planning Research, 22:1, Pages 69$81,2005$.

[6] Othman, M., "Water and development movement in Saudi Arabia." Tehama Press, Jeddah, Saudi Arabia,1984.

[7] Edgell, H. S., "Aquifers of Saudi Arabia and Their Geological Framework." The Arabian Journal for Science and Engineering, V. 22, No. 1C, Pages 3-31,1997.

[8] MEP Ministry of Economy and Planning, "The Eighth Development Plan 2005-2009." Riyadh, Saudi Arabia, 2004.

[9] MEP Ministry of Economy and Planning, "The Ninth Development Plan 2010-2014.” Riyadh, Saudi Arabia, 2010.

[10] SWCC, Saline Water Conversion Corporation, "Annual Report 2005", Riyadh, Saudi Arabia, 2005.

[11] SWCC, Saline Water Conversion Corporation, "Annual Report 2010", Riyadh, Saudi Arabia, 2010.

[12] Al-Mutaz, brahim S., "Water resources development in Riyadh, Saudi Arabia.” Desalination, Volume 64, Pages 193-202, 1987. 
[13] Allard, J. M. Rovel and Treille, P., "Potable water supply of Riyadh (the Saudi Arabia Kingdom's capital city) by reverse osmosis desalting plants.” Desalination, Volume 20, Issues 1-3, 227-237, 1977.

[14] WSA Water and Sanitary Agency Riyadh, “Annual report 2004.”, 2004.

[15] Edgell, H. S., "Geological Framework of Saudi Arabia Groundwater Resources.” J. King Abdulaziz University: Earth Sci., V. 3, pages 267289, 1989.

[16] Sharaf, M. A. M., "Review of the hydro geological and hydro chemical aspects of groundwater in the Umm-Er-Radhuma aquifer system, Arabian Peninsula." Journal of African Earth Sciences, Volume 33, Issue 2, Pages 349-362, 2001.

[17] Floyd, Frank X., "A water treatment and reuse program in Riyadh, Saudi Arabia." Desalination, Volume 30, Issue 1, Page 3211, 979.

[18] Al Mudaiheem, Raed I. S. Sami O. A. Al Yousef, Tamer Sharif and Amirul Islam, A. K. M., "Performance evaluation of ten years operation experience of brackish water RO desalination in Manfouha plants, Riyadh." Desalination, Volume 120, Issues 1-2, Selected papers presented at The Third Gulf Water Conference Towards Efficient Utilization of Water Resources in the Gulf Water Science and Technology Association (WSTA), 15 December 1998, Pages 115-120, 1998.

[19] Al-Rehail, A. M. and Alabdula'aly A, "Chemical and economical evaluation of groundwater treatment plants in Riyadh." Water Research, Volume 33, Issue 15, Pages 3291-3302, 1999.

[20] ADA, Arriyadh Development Authority, "Population Study: positive pulse of young society." Tatweer, Issue 41, Pages 16-27, 2005.

Xueliang Guo, Guoguang Zheng and Dezhen J., "A numerical comparison study of cloud seeding by silver iodide and liquid carbon dioxide." Atmospheric Research, Volume 79, Issues 3-4, March, Pages 183-226, 2006.

[21] Kossa R.M. Rajabu, "The role of participatory problem analysis in performance improvement and sustainable management of rainwater harvesting (RWH) systems: A case study of Makanya village, Tanzania." Physics and Chemistry of the Earth, Parts A/B/C, Volume 30, Issues 1116, Integrated Water Resources Management (IWRM) and the Millennium Development Goals: Managing Water for Peace and Prosperity, Pages 832-839, 2005. 